\title{
First documented records of Eastern Kingbird, Tyrannus tyrannus Linnaeus, 1758 (Aves: Tyrannidae), in Uruguay
}

\author{
María José Rodríguez-Cajarville, ${ }^{1}$ Eduardo Arballo, ${ }^{2}$ Juan Carlos Gambarotta ${ }^{3}$ \\ 1 División Ornitología, Museo Argentino de Ciencias Naturales "Bernardino Rivadavia", Av. Ángel Gallardo 470, Buenos Aires, Argentina. \\ 2 CYGNUS Wildlife Consulting, Montevideo, Uruguay. 3 Dirección Nacional de Medio Ambiente, Galicia 1133, Montevideo, Uruguay. \\ Corresponding author: María José Rodríguez-Cajarville, mjrodriguezcg@gmail.com
}

\begin{abstract}
The first documented records of Eastern Kingbird, Tyrannus tyrannus (Aves: Tyrannidae), for Uruguay are reported. The species was recorded 4 times between 1993 and 2016 in southeastern Uruguay. Due to the few records of isolated individuals we propose that the species is a vagrant in Uruguay.
\end{abstract}

Key words

South America; Campos; vagrant; new records.

Academic editor: Michael Andersen | Received 20 January 2017 | Accepted 23 May 2017 | Published 28 July 2017

Citation: Rodríguez-Cajarville MJ, Arballo E, Gambarotta JC (2017) First documented records of Eastern Kingbird, Tyrannus tyrannus Linnaeus, 1758 (Aves: Tyrannidae), in Uruguay. Check List 13 (4): 169-172. https://doi.org/10.15560/13.4.169

\section{Introduction}

The Eastern Kingbird, Tyrannus tyrannus (Linnaeus, 1758) (Passeriformes: Tyrannidae), is a migratory and widely distributed species in the Americas (Ridgely and Tudor 2009, Mobley 2016). It breeds in North America, from southern Canada to southern United States, remaining there between April and August. During the boreal winter, it migrates to South America from Colombia to central Argentina (Ridgely and Tudor 2009) (Fig. 1) where it is considered a regular visitor. In winter, the species uses forested habitats and also open terrains near water, in large and silent groups (Canevari et al. 1991). Arballo and Cravino (1999) included the species in the systematic list of the birds of Uruguay, but provided no details or photographs of any record. Later, Claramunt and Cuello (2004) excluded T. tyrannus from the list of bird species of Uruguay because of the lack of evidence, a position maintained by Claramunt and Aldabe (2016). This paper presents the first documented records of $T$. tyrannus for Uruguay.

\section{Methods}

We present information corresponding to four solitary individuals observed by the authors in 1995, 2003, 2012 and 2016 (Fig. 1). The first bird was sighted by EA on 7 May 1995 in a riparian forest along the Laguna Merin coast, in Rocha department $\left(33.1961^{\circ} \mathrm{S}, 53.6672^{\circ} \mathrm{W}\right)$ (Fig. 2). The second was also sighted by EA, on 4 January 2003 roosting on the border of a eucalyptus plantation near Route $8, \mathrm{~km} 93.5$ in Lavalleja department $\left(34.4772^{\circ} \mathrm{S}, 55.4575^{\circ} \mathrm{W}\right)$. The third record of the species was made by MJRC on 14 November 2012. The bird was on a solitary dead tree in a wetland in the north coast of Laguna Negra, near Potrerillo de Santa Teresa Biological Station, in Rocha department $\left(33.9687^{\circ} \mathrm{S}, 53.6513^{\circ} \mathrm{W}\right)$ (Fig. 3). The last record was made by JCG on 11-12 May 2016. The bird was perching on a fence and branches of short trees, catching insects at the border of a flood in Laguna de Castillos, in Rocha department $\left(34.3508^{\circ} \mathrm{S}\right.$, $\left.53.8677^{\circ} \mathrm{W}\right)$. The second and last records were not documented with photographs. 

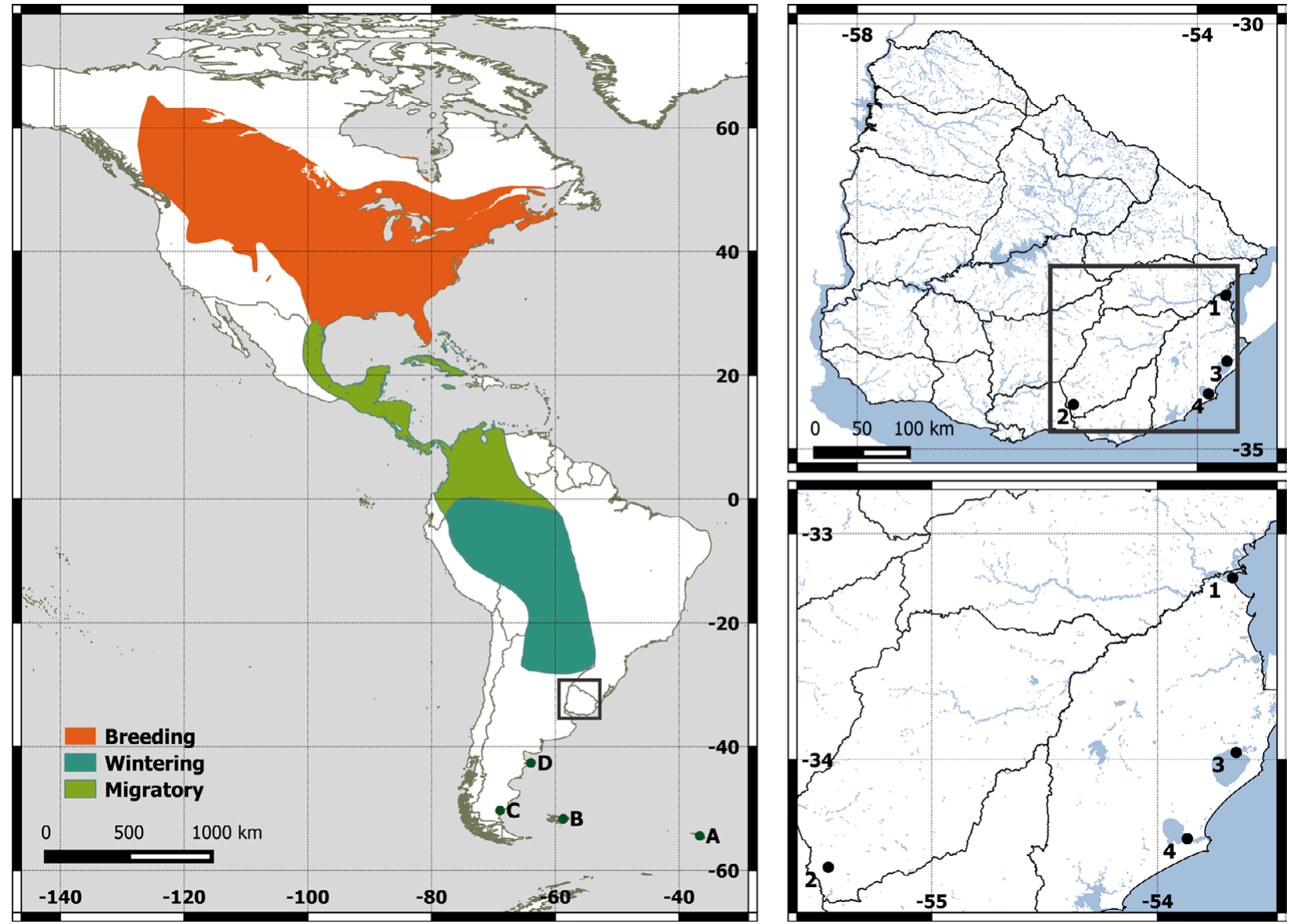

Figure 1. Distribution of Tyrannus tyrannus (BirdLife International and NatureServe, 2014). Dots indicate some remarkable sightings mentioned in text, outside the normal distribution range: (A) South Georgia Islands; (B) Falklands Islands; (C) Monte León National Park (Santa Cruz Province); (D) Península Valdés (Chubut Province). Black dots indicate the records reported in this paper for Uruguay: (1) Laguna Merin, 1995 (Rocha department); (2) Route 8, km 93.5, 2003 (Lavalleja department); (3) Potrerillo de Santa Teresa Biological Station, 2012 (Rocha department); (4) Laguna de Castillos, 2016 (Rocha department).

\section{Results}

EA and MJRC identified the species in the photographs by consulting field guides (Ridgely and Tudor 2009, Narosky and Yzurieta 2003, van Perlo 2009, Gwynne et al. 2010, Chandler et al. 1983), and the Handbook of the Birds of the World Alive (Mobley 2016). JCG has observed the species in Florida, USA, and therefore he was familiar with it. Tyrannus tyrannus is a medium-sized passerine, with black head, upper-parts blackish-grey, grey wings with grey-white coverts and secondary feathers white below, with a greyish tinge in chest and breast; rounded an black tail with a white terminal band; black bill; and legs short and black. In Uruguay the most similar species is $T$. savana, a very common, migratory species that inhabits open areas - mostly campos and open forests - and breeds in the southern cone of South America during the same season as T. tyrannus overwinter there (Ridgely and Tudor 2009, van Perlo 2009, Azpiroz 2012, Mobley 2016, Mobley and Garcia 2016). Adults of $T$. savana are very conspicuous: males and females have extremely elongated outer rectrices that make the identification unmistakable (Fig. 4), but juveniles have much shorter tails, which makes identification more difficult (Fig. 5). The juvenile of T. savana differs from T. tyran- nus mainly in the color of upper-parts and wings, which are brownish (not grayish) that contrast with the black head, the lack of the greyish tinge on chest and breast, and the shape of the tail, which is shorter than adults, but forked. The photographs of the individuals seen in Uruguay show some characters that allow the identification as T. tyrannus, as well as the discrimination from T. savana juveniles. In Figures 2 and 3, both individuals show a straight tail, blackish-grey upperparts and dark head, showing little contrast between the dorsal plumage and head. The absence of a terminal white band of the tail in the two photographed individuals could be caused by wear (Ridgely and Tudor 2009), but all other characteristics eliminate juvenile $T$. savana and support our identification of T. tyrannus. The white band of the tail was evident in the bird seen in Laguna de Castillos when perched, and was very conspicuous when the bird opened the tail in flight, often just before perching.

\section{Discussion}

The records presented in this paper represent the first through fourth records of Tyrannus tyrannus in Uruguay. The photographs allow the identification of the individu- 

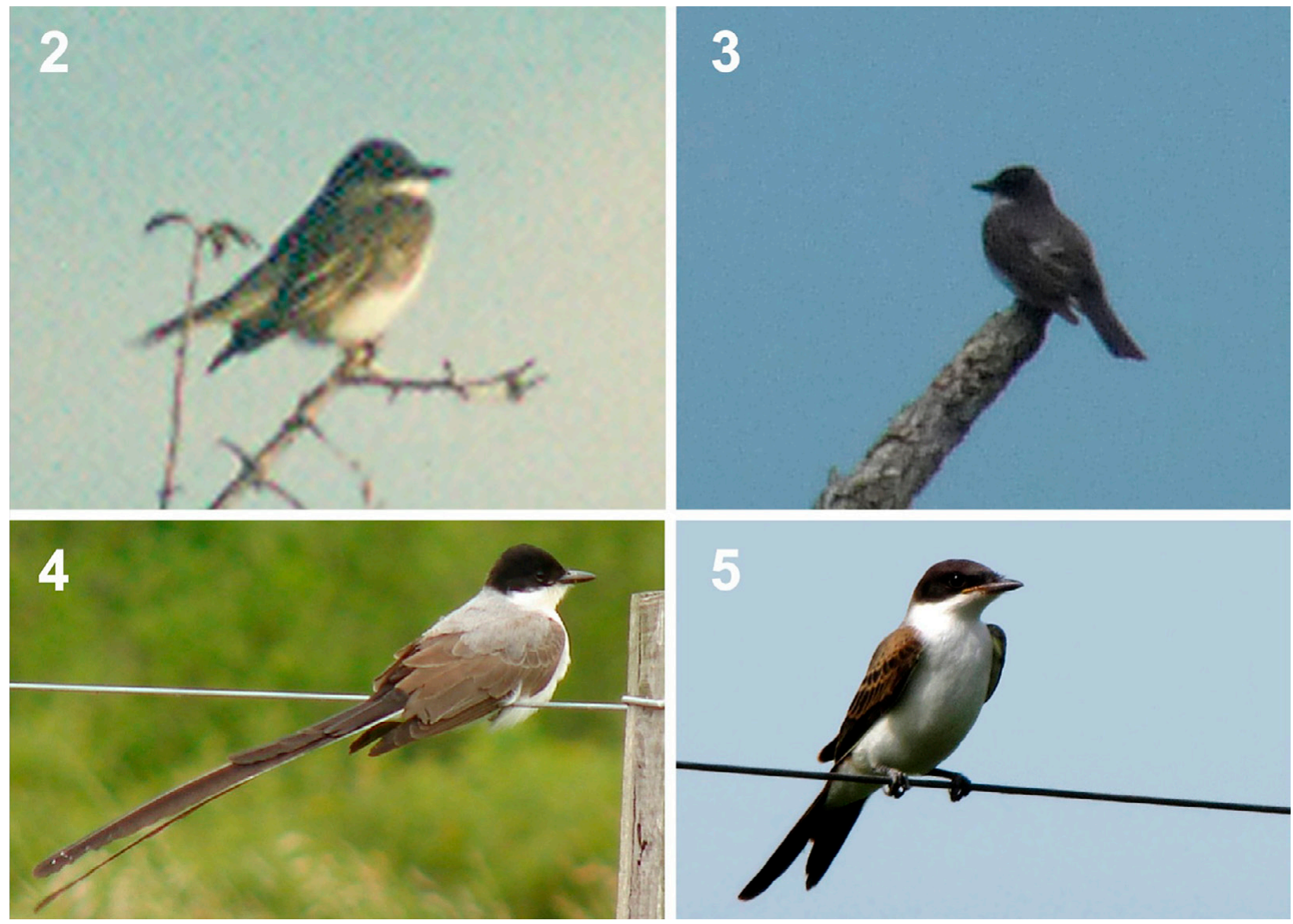

Figures 2-5. Photographs of 2 Tyrannus tyrannus recorded in Uruguay and comparison with Tyrannus savana. 2. Individual seen by EA in Laguna Merin, Rocha, 7 of May, 1995. 3. Individual seen by MJRC in Potrerillo de Santa Teresa Biological Station, Rocha, 14 of November, 2012. 4. Tyrannus savana, adult (photo by MJRC). 5. Tyrannus savana, juvenile (photo by V. Merlino).

als as T. tyrannus, as they show most of the diagnostic characters. The species is a migrant passerine that winters in South America, though usually no further south than northern Argentina. Vagrancy is common in many migratory species, especially for long-distance migrants. Tyrannus tyrannus is a long distance migrant and has been regularly found outside the normal distribution (some remarkable ones are represented in Fig. 1). The most southern record of the species is South Georgia Island (Prince and Payne 1979), followed by the Falkland Islands (Woods 1988), one record in Santa Cruz Province (Monte León National Park; Militello and Schieda 2011), and another in Chubut Province (Península Valdés, Chevez 2009). There are also some records in Chile (reviewed in Marín 2004, Barros 2010; see also Barros and Schmitt 2011), and central Argentina (reviewed in Chevez 2009, Militello and Schieda 2011), showing that vagrancy is common in the species, maybe more common than we know today because the similarity with juveniles of $T$. savana. Because of the scarcity of records (just 4 in a period of more than 20 years), and the fact that the species is gregarious in the wintering areas but the sightings were of solitary individuals, we propose that the species is a vagrant in Uruguay.

\section{Acknowledgements}

The authors express their gratitude to two anonymous reviewers for their constructive comments on the manuscript.

\section{Authors' Contributions}

EA, JCG and MJRC collected the data, MJRC wrote the text.

\section{References}

Arballo E, Cravino JL (1999) Aves del Uruguay: Manual Ornitológico. Vol. 1. Editorial Hemisferio Sur, Montevideo, $465 \mathrm{pp}$.

Azpiroz AB (2012) Aves de las Pampas y los Campos de Argentina, Brasil y Uruguay. Una Guia de Identificación. PRESSUR, Nueva Helvecia, 351 pp.

Barros R (2010) Algunas evidencias inéditas de aves raras en Chile. La Chiricoca 11 (1): 11-25.

Barros, R. and F. Schmitt. 2011. Resumen de Avistamientos. La Chiricoca 13: $30-50$

BirdLife International, NatureServe (2014) Bird Species Distribution Maps of the World. Tyrannus tyrannus. The IUCN Red List of Threatened Species. Version 2016-1. http://maps.iucnredlist.org/ map.html?id=22700506. Accessed on: 2016-11-2.

Canevari M, Canevari P, Carrizo GR, Harris G, Rodriguez-Mata J, 
Straneck RJ (1991) Nueva Guía de las Aves Argentinas. Tomo I. Acindar, Buenos Aires, Fundación, 410 pp.

Chandler, S., C.S. Robbins, B. Bruun, and H.S. Zim. 1983. Birds of North America, a guide to the field identification. Golden Press. $360 \mathrm{pp}$.

Chevez JC (2009) Otros que se Van. Fauna Argentina Amenazada. Editorial Albatros, Buenos Aires,416 pp.

Claramunt S, Aldabe J (2016) Species Lists of Birds for South American Countries and Territories: Uruguay. http://www.museum.lsu. edu/ Remsen/SACCCountryLists.htm. Accessed on: 2016-12-1.

Claramunt S, Cuello JP (2004) Diversidad de la biota uruguaya: Aves. Anales del Museo Nacional de Historia Natural y Antropología 10 (6): 1-76.

Gwynne JA, Ridgely RS, Tudor G, Argel M (2010) Aves do Brasil: Pantanal e Cerrado. Vol. 1. Editora Horizonte, New York, 322 pp.

Linnaeus C (1758) Systema Naturae per regna tria naturae secundum classes, ordines, genera, species cum characteribus, differentiis, synonymis, locis. 10th edition. Salvius, Holmiae, 824 pp. http:// dx.doi.org/10.5962/bhl.title.542

Marín M (2004) Lista Comentada de las Aves de Chile. Lynx Edicions, Barcelona, 144 pp.

Militello E, Schieda JC (2011) Primer registro del suirirí boreal (Tyran- nus tyrannus) (Passeriformes: Tyrannidae) en la provincia de Santa Cruz, Argentina. Nótulas Faunísticas 66: 1-6.

Mobley J (2016) Eastern Kingbird (Tyrannus tyrannus). In: del Hoyo J, Elliott A, Sargatal J, Christie DA, de Juana E (Eds) Handbook of the Birds of the World Alive. Lynx Edicions, Barcelona. Retrieved from http://www.hbw.com/node/57483. Accessed on: 2016-11-20

Mobley J, Garcia EFJ (2016) Fork-tailed Flycatcher (Tyrannus savana). In: del Hoyo J, Elliott A, Sargatal J, Christie DA, de Juana E (Eds) Handbook of the Birds of the World Alive. Lynx Edicions, Barcelona. Retrieved from http://www.hbw.com/node/57488. Accessed on: 2016-11-20.

Narosky T, Yzurieta D (2003) Aves de Argentina y Uruguay: guia para la identificación. Edición de Oro. Vazquez Mazzini, Buenos Aires, 346 pp.

van Perlo B (2009) A Field Guide to the Birds of Brazil. Oxford University Press, New York, 465 pp.

Prince PA, Payne MR (1979) Current status of birds at South Georgia. Bulletin of the British Antarctic Survey Bulletin 48: 103-118.

Ridgely RS, Tudor G (2009) Field Guide to the Songbirds of South America: the Passerines. University of Texas Press, Austin, 750 pp.

Woods RW (1988) Guide to Birds of the Falkland Islands. Anthony Nelson, Oswestry, 256 pp. 